\title{
AUGUST ZALESKI W DWÓCH PRZESILENIACH GABINETÓW GEN. WLADYSŁAWA SIKORSKIEGO (LIPIEC 1940 I 1941 ROK)
}

Wybuch światowego konfliktu we wrześniu 1939 roku był tragiczny w skutkach dla II Rzeczypospolitej. Po internowaniu najwyższych urzędników państwowych powołanie władz uchodźczych stało się nieuchronne. Tak więc prezydentem RP został Władysław Raczkiewicz, premierem zaś gen. Władysław Sikorski. W nowo utworzonym gabinecie znaleźli się zarówno politycy kojarzeni z obozem sanacyjnym, jak: August Zaleski czy Adam Koc, ale także działacze przedwrześniowej opozycji - gen. Sikorski, Stanisław Stroński, Stanisław Kot oraz inni ${ }^{1}$.

Uczestnikiem tych wydarzeń był dawny minister spraw zagranicznych - August Zaleski, który odegrał w dwóch kolejnych przesileniach gabinetowych znaczącą rolę. Nowy premier powierzył mu Ministerstwo Spraw Zagranicznych, który to resort w ówczesnej sytuacji politycznej miał znaczenie kluczowe. Nie bez znaczenia były dobre kontakty dyplomaty w Wielkiej Brytanii, co w połączeniu z koneksjami premiera we Francji dawało duże szanse na utrzymanie możliwie najlepszych stosunków z sojusznikami.

Jednak współpraca premiera z szefem dyplomacji nie przebiegała wzorcowo. Gen. Sikorski monopolizował oficjalne stosunki rządu z Francją. Działo się to oczywiście kosztem szefa MSZ, co doprowadziło do tarć między oboma panami. Stanisław Zabiełło jako uczestnik tamtych wydarzeń napisał, że pierwsza poważna rozgrywka między premierem a Zaleskim zakończyła się tym, że kontakty z Francuzami objął ten pierwszy, natomiast zakres stosunków z Anglikami powierzony

Mgr Joanna Pelczarska - doktorantka, Instytut Historyczny Uniwersytetu Wrocławskiego; e-mail: jb.pelczarska@gmail.com

1 Więcej: B. WANKE, Władze legalne R.P. na uchodźstwie (1940-1970), „Zeszyty Historyczne” (Paryż) 1979, nr 47, s. 87-88. 
został Zaleskiemu². Jak już wspomniano, taki podział miał swoje logiczne wytłumaczenie. Jednak nie do końca i nie zawsze miał odzwierciedlenie w rzeczywistości ${ }^{3}$.

Zmiana sytuacji rządu polskiego nadeszła razem z rozpoczęciem działań wojennych na Zachodzie wiosną 1940 roku. Było to wydarzenie, którego oczekiwano, gen. Władysław Sikorski pisał o wojnie 18 maja: „na jej rozpoczęcie czekaliśmy $\mathrm{z}$ utęsknieniem uzasadnionym"4. Atak na Francję dawał polskim władzom nadzieję na pozytywne rozstrzygnięcia dla Polski. Nikt wówczas nie spodziewał się szybkiej klęski sojusznika.

Niestety, znamienny dla tego okresu był brak kontaktu członków rządu z gen. Sikorskim, gdyż ten uparcie wierzył w zwycięstwo Francji. Sam przyznał już w Londynie, że wszystko na co liczył, zawiodło ${ }^{5}$. Pod nieobecność premiera Zaleski zajął się organizacją ewakuacji rządu. Jednak transport urzędników nie przebiegał w sposób zorganizowany i miał się okazać podstawą do oskarżeń o zaniedbania. Panowała często dezinformacja, co nie poprawiało panującej wówczas napiętej atmosfery. Dowodem tego są słowa K. Morawskiego, który po dotarciu do Bordeaux zapisał: „Rozglądaliśmy się na próżno za polską ekspozyturą rządową, gdzie można by zasięgnąć informacji i wskazówek. Traf sprawił, że [...] natknęliśmy się na [...] Augusta Zaleskiego i Jana Ciechanowskiego. [...] Powiedzieli nam krótko, że wszystko stracone. Francja gotuje się do kapitulacji”6.

Zaleski wraz z prezydentem wsiedli na brytyjski krążownik HMS „Arethusa”, którym udali się do Londynu na zaproszenie króla Jerzego VI. Do portu Plymouth dotarli 21 czerwca, a do londyńskiego dworca Paddington o godzinie 17:30. Tam czekały liczne delegacje powitalne, pojawili się: król Jerzy VI, ambasador Edward Raczyński oraz przebywający już w Londynie: minister Jan Stańczyk, wiceministrowie Zygmunt Graliński, Alfred Falter, Adam Koc i Karol Popiel. Nie przywitał jednak głowy państwa będący wówczas w Londynie, gen. Sikorski ${ }^{7}$, co było jawnym afrontem wobec Raczkiewicza, szczególnie że na dworcu pojawił

2 S. ZABiElŁo, Na posterunku we Francji, Warszawa 1967, s. 61.

${ }^{3}$ Przykładem może być wizyta Sikorskiego i Zaleskiego w Londynie w listopadzie 1939 roku. Podczas oficjalnych rozmów to premier grał pierwsze skrzypce, Zaleski zaś został odsunięty na dalszy plan: S. Stroński, Polityka rządu polskiego na uchodźstwie w latach 1939-1942, t. I, oprac. J. Piotrowski, Nowy Sącz 2007, s. 212.

${ }^{4}$ Cytat za: M. Dymarski, Stosunki wewnętrzne wśród polskiego wychodźstwa politycznego $i$ wojskowego we Francji $i$ w Wielkiej Brytanii 1939-1945, Wrocław 1999, s. 87.

5 Protokoly posiedzeń Rady Ministrów Rzeczypospolitej Polskiej, oprac. W. Rojek przy współpracy A. Suchcitza, t. II, Kraków 1995, Posiedzenie 6 VII 1940, s. 8.

${ }^{6}$ K. MoRawski, Wspólna droga z Rogerem Raczyńskim, Poznań 1998, s. 187.

7 Dzienniki czynności Prezydenta RP Władystawa Raczkiewicza 1939-1947, oprac. J. Piotrowski, t. I, Wrocław 2004, s. 180-181. 
się sam król. Dla Zaleskiego była to niewątpliwie kłopotliwa sytuacja z punktu widzenia protokołu dyplomatycznego.

Już od momentu lądowania na ziemi brytyjskiej tlił się kryzys wewnętrzny, który wybuchnąć miał w postaci przesilenia lipcowego. Spór dotyczył prezydenta, który wraz z Zaleskim wystąpił przeciw gen. Sikorskiemu oraz jego poplecznikom. Pierwszym symptomem było wspomniane już zajście na londyńskim dworcu ${ }^{8}$. Rozgorzały zarzuty względem MSZ i personalnie wobec samego ministra o złą organizację ewakuacji i pozostawienie urzędników samym sobie. Padły także oskarżenia wobec premiera o niewłaściwe zarządzanie pracami rządu podczas wojny we Francji, a raczej jego brak. Rozpoczęły się więc rozliczenia.

Co ciekawe, po przybyciu do Londynu generałowie Władysław Sikorski i Kazimierz Sosnkowski postanowili odłożyć uprzedzenia i współdziałać ${ }^{9}$. Współpraca obu generałów zaowocowała powołaniem Komitetu Ministrów pod przewodnictwem gen. Sosnkowskiego, który miał opracować program reorganizacji rządu oraz wprowadzić cięcia budżetowe. Zlikwidowane miało zostać Ministerstwo Opieki Społecznej, na czele którego stał Jan Stańczyk, co doprowadziło do pierwszego tego lata kryzysu ${ }^{10}$. Premier, chcąc utrzymać poparcie socjalistów, wycofał się jednak z proponowanych zmian reorganizacji gabinetu ${ }^{11}$.

Jeszcze tego samego dnia, 11 lipca 1940 roku prezydent wystosował do premiera stanowczy list, w którym zażądał dymisji Stanisława Kota i Henryka Strasburgera. Głowa państwa podkreślała w liście, że Kot jest politykiem, który generuje wewnętrzne konflikty w rządzie. Natomiast Strasburger powinien zostać zdymisjonowany ze względu na utratę polskiego złota, które odpłynęło do francuskiej Afryki Zachodniej ${ }^{12}$. Sikorski w odpowiedzi odrzucił prezydenckie żądania ${ }^{13}$.

Raczkiewicz zaczął poważnie rozmyślać nad zmianą rządu. Jego częstym gościem był Zaleski. Od pojawienia się na Wyspach Brytyjskich, a więc od 21 czerwca do 18 lipca obaj panowie spotkali się aż 21 razy! ${ }^{14}$ Wielu ówczesnych

${ }^{8}$ K. Kania, Edward Bernard Raczyński 1891-1993 dyplomata i polityk, Warszawa 2014, s. 195.

${ }^{9}$ I. WoJewóDzKI, Kazimierz Sosnkowski - minister stanu rządu na emigracji, w: Kazimierz Sosnkowski. Żotnierz, humanista, mąż stanu w 120. rocznicę urodzin, red. T. Głowiński i J. Kirszak, Wrocław 2005, s. 112.

10 W. BABIŃski, Przyczynki historyczne do okresu 1939-1945, Gdańsk 2015, s. 34.

11 J. RABIŃSKI, Stronnictwo Pracy we władzach naczelnych Rzeczypospolitej Polskiej na uchodźstwie w latach 1939-1945, Lublin 2012, s. 244-245.

12 T. Szumowski, Wokół przesilenia lipcowego 1940 roku, „Kwartalnik Historyczny” 1980, nr 87 , z. 1, s. $85-87$.

${ }^{13}$ M. Hulas, Goście czy intruzi? Rząd polski na uchodźstwie wrzesień 1939 - lipiec 1943, Warszawa 1996, s. 88. Odpisy listów Raczkiewicz-Sikorski w: S. STroński, Polityka rządu polskiego, s. $313-320$.

${ }^{14}$ Dzienniki czynności Prezydenta, s. 180-208. 
było zdania, że Zaleski pozostawał w bliskich kontaktach z prezydentem, świadczyć o tym może jego późniejsze stanowisko szefa Kancelarii Cywilnej Prezydenta RP. Zaleski miał informować wówczas o zaniepokojeniu władz brytyjskich przesileniem gabinetowym w polskim rządzie. Dnia 17 lipca w godzinach wieczornych Raczkiewicz oświadczył szefowi MSZ, że w wyniku zaistniałej sytuacji zmuszony jest zdymisjonować rząd i zaproponował Zaleskiemu powierzenie mu funkcji prezesa Rady Ministrów ${ }^{15}$.

Tymczasem sformowanie rządu przez szefa MSZ okazało się niemożliwe. Doszło do podobnej sytuacji, co we wrześniu 1939 roku, kiedy dwóch piłsudczyków u władzy było nie do przyjęcia dla większości stronnictw. Dla partii, które przed wybuchem wojny znajdowały się w opozycji, rząd Sikorskiego był rozwiązaniem kompromisowym, natomiast Zaleskiego nadal silnie kojarzono z obozem sanacyjnym. Sikorski nie był w Anglii rozpoznawaną personą, nie znał języka angielskiego, zaś Zaleski wydawał się lepszym kandydatem na to stanowisko. Czy sprawdziłby się jako szef rządu? Czy byłby równie uległy wobec Brytyjczyków co Sikorski? Odpowiedzi na te pytania pozostać muszą w sferze hipotez i domysłów.

Dzień 18 lipca 1940 roku był niezwykle ważny dla dalszego rozwoju wypadków. Sikorski otrzymał dymisję zapewne po godzinie 15:00 ${ }^{16}$. Najprawdopodobniej niezwłocznie skontaktował się z gen. Marianem Kukielem, który zarządził krótką naradę wyższych oficerów, na której postanowiono, iż „szef sztabu z delegacją 3 oficerów, jako rzeczników wojska, udadzą się do min. Zaleskiego z apelem, by w tak ciężkiej sytuacji, jaka została wytworzona, nie przyjmował stanowiska premiera"17.

W tym czasie Zaleski poprosił do siebie ambasadora Raczyńskiego, by „z zażenowaniem na twarzy powiedzieć, że został powołany na prezesa Rady Ministrów"18. Niedługo po tym pojawili się u niego wspomniani wcześniej oficerowie, „prosząc” o ustąpienie ze stanowiska szefa rządu. Różnie przedstawiany jest sam przebieg tej wizyty. Z jednej strony jest relacja Zygmunta Nagórskiego, który napisał:

W gabinecie ujrzałem Zaleskiego chodzącego po pokoju jak gdyby w podnieceniu czy trosce. „Zastaje mnie Pan w stanie wielkiego wzburzenia” zaczął. Przed chwilą było tu trzech oficerów, którzy mi oświadczyli, że krew się poleje w Londynie, jeżeli ja nie

\footnotetext{
${ }^{15}$ Instytut Polski i Muzeum im. Generała Sikorskiego w Londynie [dalej: IPMS], Kancelaria Cywilna i Gabinet Wojskowy Prezydenta RP [dalej: KCiGW], A.48/1/O - Przesilenie rządowe 1940, k. 9.

16 Dziennik czynności Naczelnego Wodza gen. Władysława Sikorskiego, t. I, 30 VIII 1939 31 VII 1940, red. J. Rabiński, Lublin 2016, s. 791.

${ }^{17}$ Cytat za: P. WANDYCZ, Z Pitsudskim i Sikorskim. August Zaleski minister spraw zagranicznych w latach 1926-1932 i 1939-1941, Warszawa 1999, s. 206.

18 E. RaCZYŃski, W sojuszniczym Londynie. Dziennik ambasadora Edwarda Raczyńskiego 19391945, Warszawa 1989, s. 77.
} 
ustąpię. Odparłem, że o wszystkim można mówić zawsze, ale jak Panowie zaczynają od groźby, to mogę powiedzieć jedno tylko: won! I pokazałem im drzwi ${ }^{19}$.

Podobnie scenę tę opisuje żona Zaleskiego. W swojej lakonicznej notatce zapisała, że trzej oficerowie z bronią w ręku przybyli do gabinetu jej męża i skierowali do niego groźby. Ten natomiast miał im spokojnie odpowiedzieć, że ,,to zależy od prezydenta, a ich prosił, żeby wyszli, bo on nie ma czasu" 20 .

Płk Leon Mitkiewicz przedstawia skrajnie odmienną wersję wydarzeń. Według relacji Tadeusza Klimeckiego (jednego z uczestniczących w zdarzeniu oficerów), który opowiedział o akcji następnego dnia, ambasadę opanowało nocną porą kilkunastu oficerów, którzy zmusili Zaleskiego do dymisji. Wizyta ta miała być niezwykle dramatyczna, a nowo mianowany premier miał się poddać i przedłożyć pisemne oświadczenie o rezygnacji ${ }^{21}$. Relacja wydaje się mocno przesadzona. Wiadomo o trzech oficerach, nie kilkunastu, także nocna pora budzi wątpliwości (nie wspomina o tym Raczyński), poza tym późnym wieczorem 18 lipca doszło już do kompromisu. W końcu wiemy także, że Zaleski niczego nie podpisywał, nie miałoby to zresztą znaczenia. Dodatkowo po wizycie oficerów podejmował jeszcze próby sformowania rządu, proponując jedną $\mathrm{z}$ tek ministerialnych mecenasowi Nagórskiemu ${ }^{22}$.

Najbliższa prawdy wydaje się relacja gen. Kukiela, według której jedyną osobą zbierającą głos był Tadeusz Klimecki, który miał powiedzieć Zaleskiemu, że zdymisjonowanie Sikorskiego złamałoby jedność narodową, do tego utrata generała jako naczelnego wodza wzbudziłaby ostry sprzeciw wojska. Sam nowo powołany premier z godnością miał odpowiedzieć, że nie może ulegać takim presjom. Nie ma mowy o tym, że miałaby być to wizyta o charakterze zbrojnym. Gen. Kukiel uważał, że są to tylko i wyłącznie plotki ${ }^{23}$.

Rozmowy Zaleskiego ze stronnictwami w poszukiwaniu poparcia zakończyły się fiaskiem. Desygnowany na premiera spotkał się z jednoznaczną odmową. Rozmowy z gen. Sosnkowskim także nie dały rezultatu. Generał wymijająco odniósł się do propozycji objęcia stanowiska wicepremiera lub ambasadora w Waszyngtonie $^{24}$. Zaleski sondował także, czy Sosnkowski przyjąłby funkcję naczelnego

19 Z. NAGÓRSKi, Wojna w Londynie, Paryż 1966, s. 58-59.

${ }^{20}$ Cytat za: P. WANDYCZ, Z Pitsudskim i Sikorskim, s. 206.

${ }^{21}$ L. Mitkiewicz, Z gen. Sikorskim na obczyźnie: fragmenty wspomnień, Paryż 1968, s. 79.

${ }^{22}$ Z. NAGÓRSKI, Wojna, s. 59.

${ }^{23}$ M. KukIEL, Generał Władystaw Sikorski: żotnierz i mąż stanu Polski walczacej, Londyn 1981, s. 134-135.

${ }^{24}$ Zakład Narodowy im. Ossolińskich we Wrocławiu [dalej: ZNO], Papiery Kazimierza Sosnkowskiego [dalej: PKS], Mf 8441, Dossier polityczne 1940-1941, Odręczny zapis rozmowy Kazi- 
wodza i czy myśli, że w takim wypadku prezydent i stronnictwa nie miałyby nic przeciwko połączeniu w jego rękach funkcji politycznych i wojskowych. Generał wyraził wątpliwość w możliwość realizacji misji tworzenia rządu, a swój udział uzależnił od poparcia stronnictw politycznych. W związku z tym, że do tej pory tworzenie nowego gabinetu nie znalazło entuzjastów, uważał rozmowy na ten temat za przedwczesne.

Dnia 18 lipca wieczorem odbyć się miała Rada Ministrów, która z uwagi na zaistniałą sytuację została przełożona na dzień następny. Co ciekawe, miałaby zrobić to nielegalnie, jednak przewidywano, że kryzys zostanie zażegnany. Tego samego dnia gen. Sosnkowski wieczorną porą udał się do Raczkiewicza, ,prosząc o zlikwidowanie przesilenia" ${ }^{25}$, zaproponował także mediację. W trakcie rozmowy dołączył Zaleski, który poinformował o przeprowadzonych rozmowach z przedstawicielami stronnictw oraz gen. Sosnkowskim. Od żadnej ze stron nie uzyskał definitywnej odpowiedzi, a wszyscy rozmówcy w obawie przed odpowiedzialnością uzależniali swój udział od udziału innych. Raczkiewicz po rozmowie z Zaleskim przyjął propozycję gen. Sosnkowskiego.

Przy okazji ustalania warunków mediacji pojawił się problem formuły przyszłej współpracy prezydenta z premierem w związku z pojawieniem się niejasności, wynikających z tzw. umowy paryskiej. W interpretacji ministra Strońskiego głowa państwa nie ma prawa bez zgody gabinetu odwołać premiera. Taka nadinterpretacja umowy zawartej jesienią 1939 roku w Paryżu uzyskała poparcie Rady Narodowej w postaci rezolucji, w której wyrażono troskę o losy państwa i podkreślono, że „zmiany naczelnych władz R.P. byłyby w obecnej chwili szkodliwe dla sprawy Polski”26, co dowodziło, że po stronie gen. Sikorskiego pozostawało więcej atutów.

O trudnej sytuacji prezydent postanowił poinformować Ignacego Paderewskiego. W liście z 18 lipca pisał o narastającym konflikcie z gen. Sikorskim oraz decyzji o jego zdymisjonowaniu. Podkreślał w nim, że dalsza współpraca $\mathrm{z}$ generałem była niemożliwa. Dodał też, że powołał Zaleskiego na szefa rządu ${ }^{27}$. W odpowiedzi Paderewski napisał list do Sikorskiego i Raczkiewicza, w którym podkreślił, iż „różnice [...] są w obecnej sytuacji [...] nieistotne" ${ }^{28}$. Był to kolejny argument działający na rzecz zakończenia przesilenia.

mierza Sosnkowskiego z Augustem Zaleskim z 18 lipca 1940. Więcej: I. WoJEwóDzKI, Kazimierz Sosnkowski podczas II wojny światowej: ksiązę niezłomny czy Hamlet w mundurze?, Warszawa 2009; L. WyszCZELSKI, Generat Kazimierz Sosnkowski, Warszawa 2014.

${ }^{25}$ Dzienniki czynności Prezydenta, s. 207.

26 IPMS, KCiGW, A.48/1/O - Przesilenie rządowe 1940, k. 11.

${ }^{27}$ Archiwum Akt Nowych, Archiwum Ignacego Jana Paderewskiego, sygn. 1631, k. 3.

28 Tamże, k. 4. 
Dnia 19 lipca Raczkiewicz odbył trzygodzinną rozmowę z Zaleskim, w której „wyraził mu wdzięczność za podjęcie niewdzięcznej i trudnej misji” ${ }^{29}$, wyraził także ubolewanie nad przykrością, która go spotkała w postaci najścia oficerów. Niespełna godzinę po zakończeniu tej konferencji prezydent przyjął gen. Sikorskiego, który zgodził się na przyjęcie zasad określających warunki ugody z głową państwa. Raczkiewicz podpisał dymisję Zaleskiego z funkcji premiera i ponowną nominację na prezesa Rady Ministrów gen. Sikorskiego.

Całą sytuację prezydent nazwał „burzą w szklance wody” nie bez powodu. Już 1 sierpnia wszyscy uczestnicy rządowego przesilenia spotkali się u gen. Sikorskiego na popołudniowej herbatce. Obecny był zarówno Zaleski, jak i oficerowie, którzy całkiem niedawno złożyli mu mało uprzejmą wizytę. Ten pierwszy starał się ich ignorować, co doprowadziło do sytuacji, w której wymienieni zażądali satysfakcji. Cała sprawa w myśl kodeksu Boziewicza została zakończona honorowo dla obu stron $^{30}$.

Zażegnanie przesilenia gabinetowego drogą formalną wcale nie sprawiło, że stosunki premiera z Zaleskim się poprawiły. Mimo tych chłodnych relacji czołowi polscy politycy musieli ze sobą współpracować w ramach nowego rządu, powstałego 19 lipca 1940 roku w wyniku powziętego kompromisu na szczytach władzy. Powstanie kolejnego rządu gen. Sikorskiego w nieco tylko zmienionym składzie ${ }^{31}$ oznaczało nową fazę w działalności MSZ i ministra Zaleskiego.

Zakres obowiązków szefa dyplomacji, podobnie jak we Francji, był ograniczony przez dominującego w kontaktach z Winstonem Churchillem i Franklinem D. Rooseveltem gen. Sikorskiego. Premier usuwał szefa MSZ w cień, podobnie jak przedstawiciele Wielkiej Brytanii i USA. Raczyński w swoich wspomnieniach przytacza sytuacje, kiedy to on towarzyszył Sikorskiemu podczas oficjalnych spotkań z brytyjskim premierem, nie minister Zaleski ${ }^{32}$. Szef dyplomacji podczas rozmowy z Raczkiewiczem 23 lipca 1940 roku podkreślił „konieczność należytego określenia jego funkcji, gdyż premier często występuje wobec rządu angielskiego nie tylko bez porozumienia $\mathrm{z}$ nim, ale nawet nie informując go, co stawia go w kłopotliwe położenie i umniejsza autorytet" 33 . Prezydent obiecał próbę wpłynięcia na premiera, radził też, by minister sam podjął rozmowę w tej sprawie z szefem rządu. W tym układzie sił oznaczało to przyznanie się do bezsilności.

Jedynym bodaj przykładem zgodnej współpracy ministra Zaleskiego z premierem, a także krokiem do przodu w stosunkach polsko-brytyjskich było zawarcie

\footnotetext{
${ }^{29}$ Dzienniki czynności Prezydenta, s. 209.

30 E. RaczyŃsKi, $W$ sojuszniczym Londynie, s. 79.

31 B. WANKe, Wtadze, s. 88-89.

32 E. RaczyŃsKi, $W$ sojuszniczym Londynie, s. 95.

${ }^{33}$ Dzienniki czynności Prezydenta, s. 211.
} 
umowy wojskowej. Do podpisania doszło 5 sierpnia 1940 roku. Całe wydarzenie dość szczegółowo opisuje ambasador Raczyński, podkreślając - „odbyło się to z niepraktykowanym w takich okolicznościach ceremoniałem" ${ }^{34}$. Ze strony brytyjskiej umowę sygnowali Churchill i lord Halifax, ze strony polskiej Sikorski i Zaleski. Zawarcie umowy dawało sojuszowi pełną wartość i treść, które były niezbędne do prowadzenia wspólnej wojny. Do tej pory oba państwa łączył tylko ogólny układ polityczny. Dzięki temu do momentu wybuchu wojny niemiecko-radzieckiej Polska była na pierwszym miejscu w strategii politycznej gabinetu Churchilla.

Atak Trzeciej Rzeszy na Związek Radziecki z 22 czerwca 1941 roku był zasadniczym zwrotem w sytuacji międzynarodowej zarówno pod względem militarnym, jak i politycznym. Polskie władze od 17 września 1939 roku borykały się z koniecznością zajęcia jednoznacznego stanowiska wobec Moskwy, jednak po wydarzeniach czerwcowych kwestia ta nabrała pierwszorzędnego znaczenia. Szczególnie, że zachodni alianci od początku udzielili niemal bezkrytycznego poparcia Moskwie. Widzieli oni w Stalinie silnego sprzymierzeńca, ignorując przy tym obawy Polaków ${ }^{35}$. Taka reakcja zaniepokoiła polski rząd. W swoim przemówieniu Churchill powiedział, że walka rozpoczęła się na terytorium ZSRR, podczas gdy były to okupowane ziemie polskie. Zaleski interweniował w tej sprawie i otrzymał zapewnienie Brytyjczyków o niezawieraniu wiążących zobowiązań wobec Sowietów bez porozumienia z polskimi władzami ${ }^{36}$.

Dnia 23 czerwca gen. Sikorski wygłosił przemówienie radiowe skierowane do kraju. Premier przyznał, że „stało się to, czego oczekiwaliśmy, lecz nie spodziewaliśmy się w tak szybkim czasie"37. Skrytykował także antypolską politykę Sowietów od 1918 roku oraz sojusz z Hitlerem, który doprowadził do zniknięcia Rzeczypospolitej z mapy Europy. Podkreślił, że „taki rozwój wypadków jest dla Polski wysoce korzystny" ${ }^{38}$, w związku z tym liczy na to, że Moskwa uzna pakt Ribbentrop-Mołotow za niebyły, nastąpi powrót do granic ryskich, a Polacy znajdujący się na terenie Związku Radzieckiego odzyskają wolność.

Premierowi zależało, żeby $\mathrm{w}$ tak przełomowej sytuacji postępować w pełnej harmonii z rządem brytyjskim, w związku z tym przesłał Churchillowi tekst prze-

34 E. RACZYŃSKI, W sojuszniczym Londynie, s. 80.

35 J. Piotrowski, Stosunki polsko-sowieckie w latach 1939-1943 w świetle pism polskiego ministra informacji i dokumentacji prof. Stanisława Strońskiego, w: Stosunki polityczne, wojskowe i gospodarcze Rzeczypospolitej Polskiej i Zwiazku Radzieckiego w latach II wojny światowej, red. J. Gmitruk, W. Włodarkiewicz i R. Roguski, Warszawa-Siedlce 2013, s. 48.

${ }^{36}$ Dzienniki czynności Prezydenta, s. 387.

37 Polska a wojna rosyjsko-niemiecka, „Dziennik Polski” 24 VI 1941, s. 1.

38 Naczelny Wódz do kraju o ataku Niemiec na Rosję Radziecka, ,Dziennik Żołnierza” 25 VI 1941, s. 1. 
mówienia w tłumaczeniu ${ }^{39}$. Szef rządu angielskiego skorzystał z okazji i przekazał Sikorskiemu swoje uwagi i prośbę ,ścieniowania” pewnych ustępów. Na drobne poprawki polski premier się zgodził, natomiast w kwestiach zasadniczych pozostał nieugięty.

Tuż po napaści niemieckiej na ZSRR szef Foreign Office - Anthony Eden miał do zrealizowania ważny cel. Jego zadaniem było ,przywrócenie stosunków pomiędzy rządem radzieckim a rządem polskim"40. W tej sprawie rozmawiał wielokrotnie w lipcu 1941 roku z polskim premierem. Co ciekawe, w swoich pamiętnikach nie wspomina o Zaleskim, który jako szef MSZ był zaangażowany w rozmowy. Brytyjski dyplomata stał się ogniwem łączącym stronę polską z radzieckim ambasadorem Iwanem Majskim.

Ustalono, że w ciągu siedmiu do dziesięciu dni polski rząd nie podejmie własnej inicjatywy w kierunku porozumienia ze Związkiem Radzieckim. Zdanie to podzielał zarówno prezydent, który zalecił Sikorskiemu „,ierpliwe wyczekanie zajęcia przez Moskwę wyraźnego stanowiska"41, jak i Zaleski, który twierdził, że należy działać ostrożnie, ponieważ nie są znane intencje Sowietów ${ }^{42}$.

Kolejne dni mijały w napiętym wyczekiwaniu. Zastanawiano się, dlaczego strona radziecka nie podejmuje kontaktu. Dopiero 4 lipca ambasador Majski wręczył Edenowi odpowiedź na deklaracje w przemówieniu Sikorskiego. Jak stwierdził sam szef Foreign Office, odpowiedź ta nie była zbyt jasno sformułowana. Według niej w ZSRR miały powstawać komitety narodowe Polaków, Czechów i Jugosłowian, które miałyby mieć możliwość tworzenia własnych sił zbrojnych. W myśl tego polscy jeńcy mieliby zostać zwolnieni. Dodatkowo była mowa dość ogólnie o niezależnym państwie polskim i ewentualnym traktacie, który miałby dotyczyć wspólnego frontu przeciw Niemcom ${ }^{43}$.

Polski premier wyraził dezaprobatę wobec odtworzenia panslawizmu pod flagą Sowietów. Eden wykazał pełne zrozumienie dla polskiego stanowiska. Mimo obiekcji, Sikorski zgodził się na podjęcie rozmów, po wcześniejszej konsultacji z Radą Ministrów. Powtórzył także podstawowe postulaty strony polskiej, które miały się stać fundamentem przyszłych rokowañ ${ }^{44}$. Co znamienne, w spotkaniu tym

39 Protokoty posiedzeń Rady Ministrów Rzeczypospolitej Polskiej, oprac. W. Rojek przy współpracy A. Suchcitza, t. III, Kraków 1996, Posiedzenie 23 VI 1941, s. 2.

40 A. EdEn, Pamiętniki 1938-1945, t. II, Warszawa 1972, s. 214.

${ }^{41}$ Dzienniki czynności Prezydenta, s. 388.

42 IPMS, KCiGW, A.48/2/C3 - Sprawa podpisania umowy polsko-sowieckiej, teczka Zaleskiego, k. 2.

${ }^{43}$ A. Eden, Pamiętniki, s. 214-215.

44 IPMS, KCiGW, A.48/2/C3 - Sprawa podpisania umowy polsko-sowieckiej, teczka Zaleskiego, k. 4. 
nie uczestniczył Zaleski, jednak był to dopiero początek sukcesywnego pomijania go w trudnych rokowaniach z Moskwą.

Do rozmowy obu stron doszło 5 lipca 1941 roku na neutralnym gruncie Foreign Office. Stronę polską reprezentowali premier oraz Zaleski, zaś brytyjskim mediatorem był zastępca Edena, Alexander Cadogan. Dyplomata ten określił postępowanie Sikorskiego jako bardzo dobre, natomiast o Zaleskim napisał, że jego obecność nie pomoże w rokowaniach ${ }^{45}$. Świadczy to o nastawieniu Zaleskiego do prowadzenia negocjacji ze Związkiem Radzieckim, a także jak pisze ambasador Raczyński: „rozmowy od pierwszej chwili prowadzone były przez samego premiera Sikorskiego obok p. Zaleskiego, przy czym strona angielska (Eden) w sposób niemal brutalny odsuwała polskiego ministra spraw zagranicznych od stołu obrad"46. Możliwie też, że Zaleski pojawił się głównie w charakterze tłumacza, a nie partnera w rokowaniach. Sama rozmowa nie przebiegała bez trudności. Majski odmówił dyskusji o przywróceniu granicy z traktatu ryskiego, podkreślił też, że Związek Radziecki popiera Polskę w granicach etnicznych. Sikorski zgodził się na odłożenie kwestii granic na okres późniejszy, jednak nie chciał ustąpić w sprawie unieważnienia przez ZSRR układów radziecko-niemieckich z 1939 roku. Domagał się także nawiązania stosunków dyplomatycznych (co faktycznie oznaczało uznanie polskiego rządu), zwolnienia polskich obywateli więzionych na terenie Związku Radzieckiego oraz utworzenia z nich polskiej armii, która podlegałaby rządowi RP. Premier zaznaczył, że jest gotów zawrzeć umowę, jeżeli te punkty zostaną przyjęte.

Spotkanie to, mimo że stanowiło dopiero początek rokowań polsko-radzieckich, było niezwykle istotne. Moskwa wycofała się ze stanowiska przyjętego w 1939 roku, uznała istnienie polskiej państwowości i polskiego rządu, miała się też zgodzić na nominację ambasadora polskiego w Moskwie, a także uznać polską armię za sojusznika w wojnie ${ }^{47}$.

Zaleski nie będąc przekonany co do intencji ZSRR, nakłonił Sikorskiego, aby złożyć ministrowi Edenowi notę oraz memorandum precyzujące polski punkt widzenia. Pierwszy z dokumentów obrazował oficjalne stanowisko rządu, drugi opinię Zaleskiego dotyczącą polityki radzieckiej w latach 1939-1940. W tym samym dniu (tj. 8 lipca) Sikorski zażądał od MSZ przesłania projektu umowy polsko- radzieckiej ${ }^{48}$. Premier chciał przez to dać do zrozumienia kierownikowi resortu,

45 J. TeBinKa, Wielka Brytania dotrzyma lojalnie swojego stowa" Winston S. Churchill a Polska, Warszawa 2013, s. 74-75.

46 E. RaCzyŃsKi, $W$ sojuszniczym Londynie, s. 119.

47 W. BABIŃski, Przyczynki historyczne, s. 55-56.

48 IPMS, KCiGW, A.48/2/C3 - Sprawa podpisania umowy polsko-sowieckiej, teczka Zaleskiego, k. 6 . 
że zamierza sam prowadzić rozmowy w tej sprawie, co odpowiadało zarówno Sowietom, jak i Brytyjczykom.

Ponowne spotkanie miało miejsce 11 lipca. Obecni ze strony polskiej byli ponownie Sikorski i Zaleski, towarzyszył im w spotkaniu Eden. Majski zgodnie zaproponował zawarcie układu polsko-sowieckiego, który miałby zawierać cztery punkty ${ }^{49}$. Po pierwsze - unieważnienie układów niemiecko-radzieckich z 1939 roku, po drugie - nawiązanie stosunków dyplomatycznych między oboma krajami, po trzecie - utworzenie armii polskiej na terenie ZSRR i po czwarte - sily militarne polskie i radzieckie miałyby współpracować przeciw Niemcom. Sikorski podkreślił, że aby do współpracy mogło dojść, potrzebne są jeszcze oświadczenia ze strony ZSRR: o zwolnieniu więzionych Polaków oraz o zwrocie polskiego i prywatnego majątku zagrabionego po 17 września 1939 roku. Majski zaproponował, żeby kwestie te odłożyć na okres późniejszy, kiedy zostanie już mianowany polski ambasador w Moskwie. Sikorski chciał także potwierdzenia stanu prawnego i terytorialnego, co ambasador sowiecki odrzucił, chcąc i tę sprawę odłożyć na późniejsze szczegółowe dyskusje. Eden mając jasny cel, aby do porozumienia doszło, próbował uspokoić każdą ze stron i załagodzić konflikty ${ }^{50}$.

Następnego dnia Zaleski przesłał do Foreign Office formalny projekt przyszłego traktatu. Podobnie Eden przesłał polskiej stronie swoją propozycję układu opartego na głównych tezach omawianych na spotkaniu z 11 lipca. Obie strony wymieniały jeszcze propozycje. W sprawie uwolnienia polskich więźniów u samego Stalina interweniował ambasador Stafford Cripps, uzyskując zgodę.

Kiedy 12 lipca podpisano brytyjsko-radziecki układ sojuszniczy, Brytyjczycy zaczęli wywierać silniejszą presję na Polaków. Tymczasem w rządzie pojawiały się trudności, ponieważ minister Zaleski, gen. Sosnkowski oraz minister Seyda przy poparciu prezydenta sprzeciwiali się zawarciu porozumienia z Moskwą, bez uznania nienaruszalności polskich granic wschodnich sprzed wojny. Minister spraw zagranicznych postanowił przesłać Edenowi oficjalny polski kontrprojekt podkreślający wagę polskich granic na wschodzie, a właściwie wnosił o doprecyzowanie tej kwestii, co Sikorski poparł.

Jednak dwa dni później premier przesłał krytyczne uwagi dotyczące kontrprojektu Zaleskiego i w praktyce nakazał przywrócić tezy Majskiego. Szef MSZ był tym zachowaniem mocno zaskoczony. Główna różnica polegała na pominięciu wzmianki o uwolnieniu więźniów oraz pozostawienie niejasności w sprawie wschodniej granicy. Wahania premiera miały swoją przyczynę w naciskach ze

49 E. DuRACZYŃSKI, Rząd polski na uchodźstwie 1939-1945, Warszawa 1993, s. 111.

${ }^{50}$ IPMS, KCiGW, A.48/2/C3 - Sprawa podpisania umowy polsko-sowieckiej, teczka Zaleskiego, k. 8 . 
strony brytyjskiej ${ }^{51}$. Dnia 14 lipca Zaleski odbył jeszcze rozmowę z lordem Vansittartem, mając nadzieję na zrozumienie polskiego punktu widzenia i wstawiennictwo u ministra Edena. Sam Vansittart stwierdził, że w „F. O. [Foreign Office - J.P.] powiedziano mu, że Rząd Polski stawia zbyt wygórowane warunki" ${ }^{\text {52 }}$, jednak po rozmowie z polskim szefem dyplomacji przyznał polskiemu stanowisku słuszność i obiecał porozmawiać z Edenem.

Kolejnego dnia Sikorski z rana odbył rozmowę z Zaleskim, któremu oznajmił, że w jego ocenie MSZ sabotuje rozmowy z ZSRR. Poinformował go także, że telefonował do niego Churchill, który powiedział, że układ polsko-radziecki musi zostać zawarty. Zaleski mimo ogólnej niechęci, udał się jeszcze do zwierzchnika Foreign Office, u którego dokonano poprawek w tekście traktatu. Brytyjczycy nie zgodzili się jednak, żeby polskie MSZ bez pośpiechu dokonało kolejnych korekt.

Ustalenie ostatecznej wersji tekstu układu polsko-sowieckiego potrwało jeszcze kilka tygodni. Sikorski był przekonany o konieczności jak najszybszego zawarcia porozumienia z Sowietami, jednak nie podjął w tej ważnej kwestii bliskiej współpracy $\mathrm{z}$ resortem spraw zagranicznych i jego szefem. Konsekwentnie odsuwał ministra od rokowań, samodzielnie wprowadzając poprawki do tekstu układu. Zaleski w notatce z 17 lipca pisał, iż udał się w godzinach popołudniowych do gen. Sikorskiego wraz z radcami Kulskim i Potulickim celem opracowania poprawek do projektu porozumienia, jednak ,gdy przybyliśmy, poprawki były już gotowe"53. Prezes Rady Ministrów poprosił jedynie o pomoc w przetłumaczeniu ich na język angielski i przesłanie ministrowi Edenowi, co potwierdza hipotezę o uczestnictwie w rozmowach ministra Zaleskiego tylko w charakterze thumacza. Tak więc „do redakcji jednego z najbardziej drażliwych i kontrowersyjnych dokumentów dyplomatycznych z okresu ostatniej wojny premier zasiadł sam"54. Świadomie odrzucił pomoc doświadczonego dyplomaty, a także grona profesjonalistów z MSZ, sam nie mając biegłości w tego typu przedsięwzięciach.

W drugiej połowie lipca odbyły się dwa burzliwe posiedzenia Rady Ministrów. Jednak to posiedzenie z 25 lipca okazało się kluczowe dla przyszłości polskiego rządu. Wtedy premier poinformował swój gabinet o odrzuceniu przez rząd sowiecki polskich poprawek do projektu układu. Dodał też, że Sowieci niechętnie i tylko pod naciskiem brytyjskim zgodzili się na utworzenie polskich sił zbrojnych na terenie ZSRR. Moskwa obstawała przy tajności protokołu dotyczącego uwolnienia więźniów i pretensji. Sikorski w związku z zaistniałą sytuacją odbył rozmowę

${ }^{51}$ IPMS, KCiGW, A.48/2/C3 - Sprawa podpisania umowy polsko-sowieckiej, teczka Zaleskiego, k. 11.

52 Tamże, k. 12.

53 Tamże, k. 19.

54 K. Morawski, Wspólna droga, s. 213. 
z Edenem, który wprost powiedział, że nie ma możliwości wynegocjowania czegokolwiek więcej. Brytyjski minister podsumował sytuację słowami, że „odrzucenie podpisania układu w obecnej formie [...] podcięłoby obecne stanowisko Polski w świecie anglosaskim" "55. Zatem szef polskiego rządu poprosił obecnych członków gabinetu o podjęcie decyzji o podpisaniu bądź odrzuceniu układu.

Minister Seyda wraz z gen. Sosnkowskim opowiedzieli się przeciw podpisywaniu układu, powołując się już na swoje wcześniejsze argumenty ${ }^{56}$. Natomiast ministrowie Strasburger, Kot, Stańczyk, Stroński i gen. Haller za. Część z nich zrobiła to nie bez wątpliwości, jednak przyznali słuszność argumentacji szefa rządu. Premier przed zakończeniem posiedzenia dodał, że: „Ci zaś, którzy w takiej chwili przeciwstawiają się solidarności rządu, muszą z takiego stanowiska wyciągnąć najdalej idące konsekwencje" ${ }^{, 57}$.

Pozostał jeszcze jeden członek gabinetu - minister Zaleski. Bez wątpienia był sceptycznie nastawiony do narzuconego tekstu układu, ale zdawał sobie sprawę z powagi sytuacji. Zależało mu na niebudzących wątpliwości sformułowaniach w treści porozumienia polsko-radzieckiego, a także otrzymaniu wiążących gwarancji ze strony Brytyjczyków w kwestiach terytorialnych. Zaniepokoiło go także żądanie tajności protokołu dotyczącego uwolnienia więźniów oraz pretensji polskich. Był jednak powściągliwy. Po latach gen. Sosnkowski w liście do Tadeusza Schaezla napisał:

Czy Pan nie sądzi [...] że gdyby Zaleski objął ster rządów w roku 1940-ym, rok 1941-y miałby przebieg lepszy dla sprawy naszej? Czy Pan pamięta, że podczas dramatycznego posiedzenia rządu, jakie poprzedziło dymisję trzech ministrów, Zaleski na pytanie Sikorskiego [...] odpowiedział, iż pozostanie w rządzie i na układ polsko-sowiecki w proponowanym brzemieniu wyrazi zgodę, jeśli wSZYSTKIE STRONNICTWA rządowe zajmą wobec projektu stanowisko przychylne. Tak więc niezłomny Minister Spraw Zagranicznych uzależnił swe stanowisko od opinii partyjnych ${ }^{58}$.

Istotnie, Zaleski nie zajął początkowo konkretnego stanowiska, wahał się. W słowach listu przebija ogromne rozgoryczenie Sosnkowskiego, że po latach Zaleski (w chwili napisania listu Prezydent RP na uchodźstwie) został wyniesiony do rangi bohatera. Generał podważał tę opinię ,niezłomnego ministra”, który zawsze wierny był swoim ideałom.

55 Protokoty, Posiedzenie 25 VII 1941, t. III, s. 97.

56 Protokoty, Posiedzenie 21 VII 1941, t. III, s. 85-87 i 90-91.

57 Protokoty, Posiedzenie 25 VII 1941, t. III, s. 103.

58 Papiery prof. Wojciecha Wrzesińskiego, Instytut Historyczny UWr., Ksero listu gen. Kazimierza Sosnkowskiego do Tadeusza Schaezla z dnia 28 grudnia 1958 roku. 
W istocie Zaleski nie pojawił się osobiście na posiedzeniu o godz. 18:15, kiedy miano przeprowadzić głosowanie w sprawie traktatu polsko-radzieckiego. Dopiero post factum wraz z gen. Sosnkowskim i ministrem Seydą podał się do dymisji. Minister prawdopodobnie liczył jeszcze na ugranie lepszych warunków układu. Miał nadzieję, że poparcie Waszyngtonu wzmocni polską pozycję. Tymczasem wobec braku sprzeciwu w łonie rządu, po dymisjach trzech członków gabinetu, Rada Ministrów jednomyślnie wypowiedziała się za podpisaniem układu ${ }^{59}$.

Dnia 30 lipca w godzinach popołudniowych Sikorski i Majski w obecności Churchilla i Edena podpisali w Foreign Office traktat polsko-sowiecki. Znalazło się w nim kilka punktów, które w zasadzie zostały uzgodnione już 11 lipca: 1) unieważnienie przez Związek Radziecki układów z Niemcami z roku 1939 wraz $\mathrm{z}$ oświadczeniem Polski, że ta nie jest z żadnym państwem związana przeciw ZSRR; 2) przywrócenie stosunków dyplomatycznych; 3) udzielenie sobie wzajemnej pomocy w walce przeciw III Rzeszy; 4) powstanie armii polskiej na terenie ZSRR, która politycznie będzie podlegała polskiemu rządowi, natomiast operacyjnie dowództwu sowieckiemu; ostatni piąty punkt dotyczył kwestii natury prawnej, że traktat ten nie wymaga ratyfikacji i wchodzi w życie wraz z chwilą podpisania. Dołączone zostały jeszcze dwa protokoły, jeden jawny - mówiący o udzieleniu amnestii polskim obywatelom więzionym w Związku Radzieckim, drugi tajny - o rozstrzyganiu spraw roszczeń o odszkodowania wyłącznie drogą dyplomatycznych rokowań ${ }^{60}$.

Całość minister Eden skomentował w ten sposób: ,jeśli komuś należała się za to pochwała, to gen. Sikorskiemu za jego walory męża stanu. Nasz udział polegał na cierpliwej dyplomacji zabarwionej niepokojem o przyszły los Polaków jako słabszego partnera"61. Szef Foreign Office doprowadził powierzone mu zadanie do „szczęśliwego” zakończenia.

W kolejnych dniach prasa polska na uchodźstwie rozpisywała się już o zawartym układzie polsko-sowieckim ${ }^{62}$. Opublikowano przemówienie gen. Sikorskiego, który mówił o tym, że dzięki traktatowi Polska zacieśni więzy z Wielką Brytanią

\footnotetext{
59 Protokoly, Posiedzenie 25 VII 1941, t. III, s. 104.

60 J. TeBInKA, Polityka brytyjska wobec problemu granicy polsko-radzieckiej 1939-1945, Warszawa 1998, s. 155-156.

${ }^{61}$ A. EDEn, Pamiętniki, s. 216.

${ }^{62}$ Układ polsko-sowiecki podpisany, „Dziennik Żołnierza” 31 VII 1941, s. 1; Znaczenie układu polsko-sowieckiego. Mowa Premiera i Naczelnego Wodza gen. Władysława Sikorskiego, „Dziennik Żołnierza” 1 VIII 1941, s. 1; Umowa między Polska a Z.S.R.R., „Dziennik Polski” 31 VII 1941, s. 1; Godny i honorowy układ. Przemówienie gen. Sikorskiego do kraju wygłoszone z powodu podpisania umowy polsko-sowieckiej, „Dziennik Polski” 1 VIII 1941, s. 1; Znaczenie umowy polsko-rosyjskiej, „Dziennik Polski” 2 VIII 1941, s. 1.
} 
i Stanami Zjednoczonymi. Podkreślił, że podpisując układ, rząd z niczego nie zrezygnował, przyjdzie jeszcze czas na omówienie kwestii granic.

Po dłuższym oporze Raczkiewicza Zaleski został oficjalnie zwolniony z urzędu 22 sierpnia 1941 roku. Następnego dnia były minister spraw zagranicznych wystosował list otwarty, zatytułowany Do mego nastepcy na stanowisku Ministra Spraw Zagranicznych $R P^{63}$. Adresatem tekstu był ambasador Raczyński, który przejął obowiązki Zaleskiego w MSZ, na razie bez tytułu ministra. Dokument ten liczy 11 stron maszynopisu. Częściowo jest to omówienie bieżącej sytuacji na arenie międzynarodowej, a częściowo ogólna refleksja byłego ministra dotycząca położenia Polski.

Zaleski nawiązał w nim do przeszłości, że już po raz drugi ustępuje ze stanowiska ministra spraw zagranicznych. Napisał o tym, że w roku 1941 powtórzyła się sytuacja, kiedy ,panujące w roku 1932 w Polsce warunki wewnętrzne nie pozwoliły mi jasno i otwarcie wypowiedzieć prawdziwych powodów mego ustąpienia" ${ }^{94}$. Zaleski podkreślał w ten sposób, że nie może sobie pozwolić na szczerość w obawie o reperkusje dla Polski.

W ten oto sposób Zaleski po raz drugi pożegnał się z MSZ. S. Zabiełło nieprzychylnie napisał o nim: ,na pewno był sceptykiem i nie stać go było na stawienie czoła nawałnicom. W trudnej sytuacji potrafił tylko, jak w 1941 roku, podać się do dymisji” ${ }^{65}$. Jednak nie był to koniec politycznej kariery ministra Zaleskiego. Zapewne sam zainteresowany w chwili ustąpienia nie zdawał sobie sprawy, że odegra jeszcze istotną rolę na kartach historii polskiego wychodźstwa niepodległościowego. Wyniósł z wydarzeń roku 1940 i 1941 ważną naukę, którą wydaje się $\mathrm{w}$ pełni wykorzystał $\mathrm{w}$ czasie swojej prezydentury, kiedy uznawany był za głowę państwa nieakceptującą żadnych półśrodków i kompromisów w sprawach o zasadniczym znaczeniu.

W obu przesileniach rządowych (1940 i 1941 roku) wystąpił jako przeciwnik (konkurent) wobec gen. Sikorskiego i jego polityki. Jednak w przeciwieństwie do swego adwersarza nie dysponował własnym zapleczem politycznym. W tym - jak sądzę - leżała przyczyna jego ówczesnych niepowodzeń. Obóz piłsudczykowski - z którego się wywodził - był wówczas po klęsce wrześniowej 1939 roku nadal mocno niepopularny, zatem minister mógł liczyć (obok poparcia słabego na uchodźstwie prezydenta) tylko na siebie. Tymczasem - jak wiemy nie od dziś polityka to gra zespołowa, dlatego w omówionych przesileniach poniósł porażkę.

${ }^{63}$ ZNO, PKS, Mf 8442, Sprawy ogólno-polityczne 1940-1941, List otwarty Augusta Zaleskiego Do mego nastepcy na stanowisku Ministra Spraw Zagranicznych RP, 23 VIII 1941.

${ }^{64}$ Tamże.

65 S. ZABIELlo, Na posterunku, s. 56. 


\section{BIBLIOGRAFIA}

BABIŃSKi W., Przyczynki historyczne do okresu 1939-1945, Gdańsk: Finna 2015.

EDEN A., Pamiętniki 1938-1945, Warszawa: PAX 1970.

HuŁas M., Goście czy intruzi? Rząd polski na uchodźstwie wrzesień 1939 - lipiec 1943, Warszawa: Instytut Historii PAN 1996.

KANIA K., Edward Bernard Raczyński 1891-1993 dyplomata i polityk, Warszawa: Neriton 2014.

Kukiel M., Generał Władysław Sikorski: żołnierz i mąż stanu Polski walczącej, Londyn: Instytut Polski i Muzeum im. Gen. Sikorskiego 1970.

Morawski K., Wspólna droga z Rogerem Raczyńskim, Poznań: Wydawnictwo Poznańskie 1998.

NAGóRSKi Z., Wojna w Londynie. Wspomnienia 1939-1945, Paryż: Księgarnia Polska w Paryżu 1966.

RACZYŃSKi E., W sojuszniczym Londynie. Dziennik ambasadora Edwarda Raczyńskiego 1939-1945, Warszawa: Niezależna Oficyna Wydawnicza 1989.

\section{AUGUST ZALESKI W DWÓCH PRZESILENIACH GABINETÓW GEN. WŁADYSŁAWA SIKORSKIEGO (LIPIEC 1940 I 1941 ROK)}

Streszczenie

Artykuł omawia rolę Augusta Zaleskiego w przesileniach gabinetowych gen. Władysława Sikorskiego w 1940 i 1941 roku. Wymieniony dyplomata w latach II wojny światowej po raz kolejny w swojej karierze stanął na czele Ministerstwa Spraw Zagranicznych, jednak nie posiadał pełnej niezależności w pełnieniu swojej funkcji - musiał liczyć się z premierem. Autorka zwraca uwagę na napięte stosunki na linii Zaleski-Sikorski, które kładły cień na kolejne problemy, z którymi musiał borykać się rząd na uchodźstwie. Punktami kulminacyjnymi tej relacji były dwa przesilenia gabinetowe, kiedy dochodziło do próby sił, z których jednak Zaleski nie mógł wyjść zwycięsko.

Słowa kluczowe: August Zaleski; rząd na uchodźstwie; rząd gen. Władysława Sikorskiego; pakt Sikorski-Majski 


\section{THE ROLE OF AUGUST ZALESKI IN TWO CRISES FACED BY THE GOVERNMENT OF WŁADYSŁAW SIKORSKI}

(JULY, 1940 AND 1941)

Sum mary

The article presents the role of August Zaleski in two crises that the government of Władysław Sikorski faced in 1940 and 1941. That diplomat was the Foreign Secretary for the second time in his career during The Second World War, nevertheless he was not fully independent in performing his function as Zaleski had to submit to Sikorski's opinions. The author emphasises strained relations between Zaleski and Sikorski, which cast a shadow over the future problems of the Polish government in exile. That relations reached their climax in 1940 and 1941, when two crises of Polish cabinet in London occured. The conflict between the Prime Minister and Foreign Secretary escalated, which was the situation Zaleski could not win.

Key words: August Zaleski; the Polish government in exile; the government of Władysław Sikorski; Sikorski-Maysky pact 